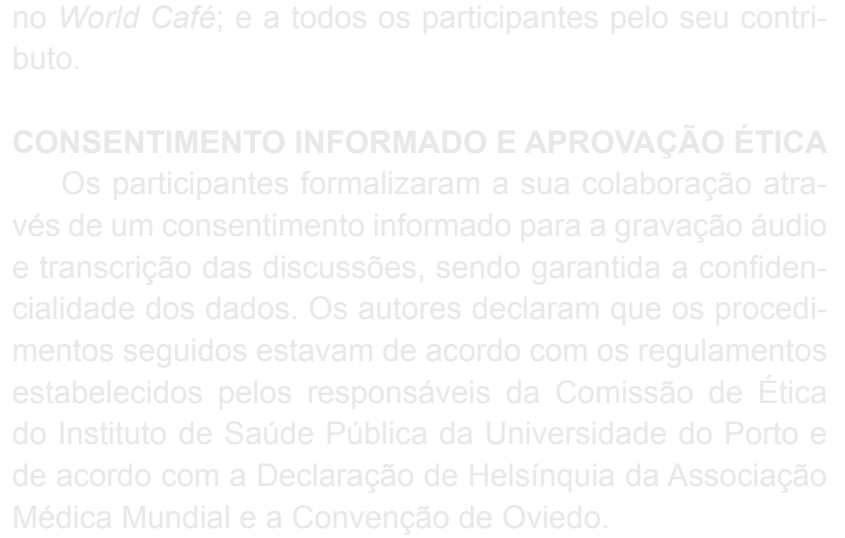

CONFLITOS DE INTERESSE
Os autores declaram não ter quaisquer conflitos de inte-
resse relativamente ao presente artigo.
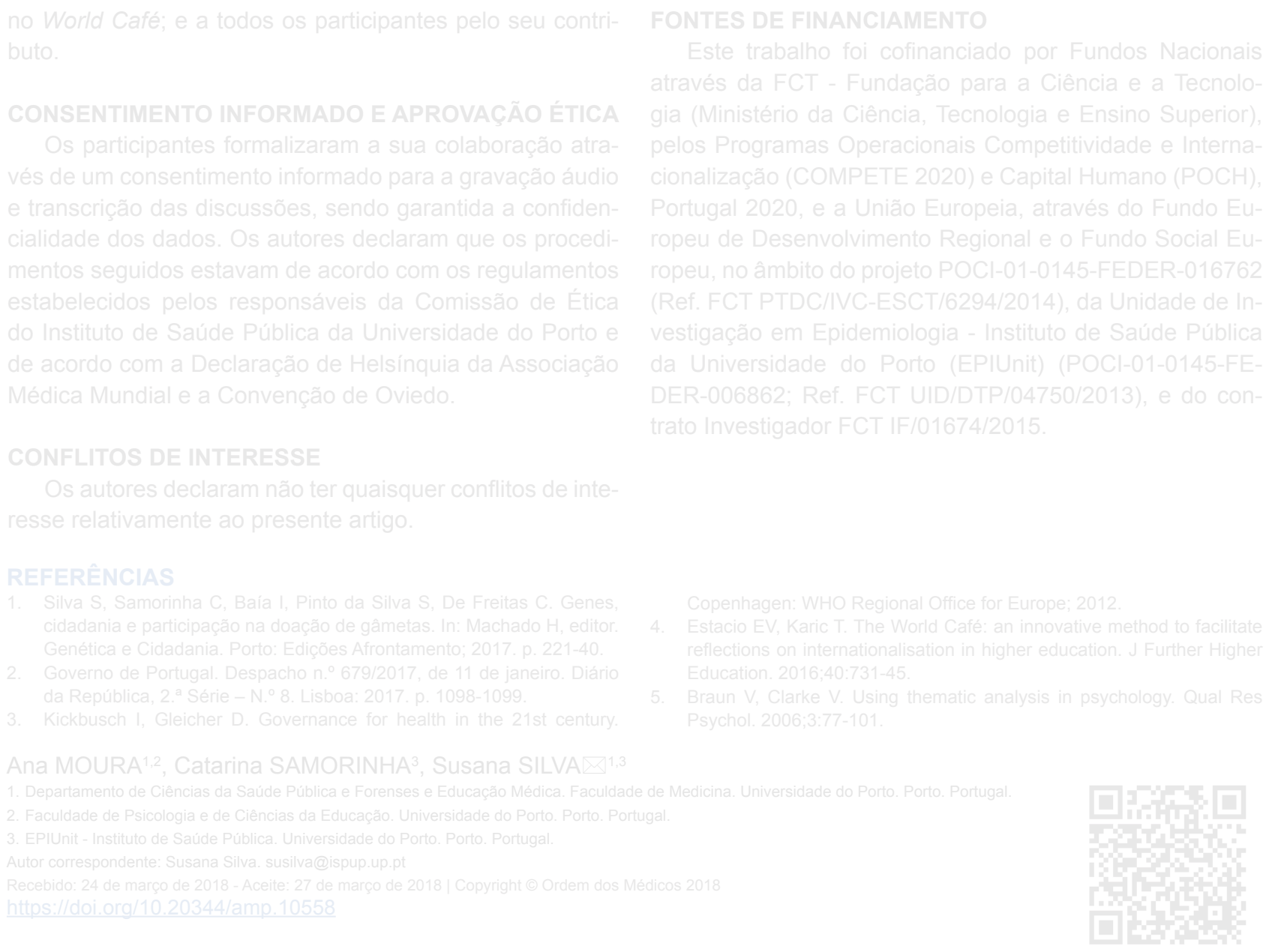

\section{Letter to the Editor: Still Regarding Predatory Publishing}

Carta ao Editor: Ainda a Propósito da Publicação Predatória

Keywords: Open Access Publishing; Publishing Palavras-chave: Publicação; Publicação em Acesso Livre

\section{Dear Editor,}

We read with great interest, in the previous issue of this journal, one article and one letter to the editor, regarding the topic of predatory publishing. While reading these papers, we realized, with great pleasure, that both medical students from our small country ${ }^{1}$ and top international medical journals' editors ${ }^{2}$ are deeply concerned with one of the worst enemies of true and honest science: predatory publishing!

Although our experience is relatively small we have been receiving in the last decade, dozens of monthly invitations from obscure journals, more or less recognizable at the already classic Beall's blog. ${ }^{3}$ Now that Jeffrey Beall stopped updating this ever growing list we have a significant gap in the scholarly communications ecosystem, but there are already some companies assigning dedicated staff to the maintenance of this kind of lists. ${ }^{4}$ But, unfortunately, we do not believe that it will be free of charge. So, in a not so distant future, we may be seeing ourselves paying to get access to the name of the journals that are OK or not OK to publish with. Following what may become another profitable business, some scholarly analytics enterprises were really fast and have already gathered their own 'black lists'. ${ }^{5}$

In spite of this dramatic situation we would like to highlight that there are some researchers that, ironically, have been studying the predatory publishing phenomena itself, using their financial resources to pay for the article processing charges of their intentionally created fake articles. After publishing those papers (some of them incredibly creative or bizarre) the author shows them to his peers as a proof that no serious editor or reviewer has been through the manuscripts, denouncing all the fraud on the publishing process. This kind of funny experiences has been done for more than a decade. ${ }^{6}$

Finally if our reader gets tired of receiving unwanted e-mails with invitations for predatory publishing, one can always create your own random pseudo-scientific paper and submit it just for fun ${ }^{7}$... we are very curious, indeed, to see what will happen to scientific publishing, in the next decade as we're living fascinating times of internet-fueled globalization. 


\section{REFERENCES}

1. Revés J, Silva BM, Durão J, Ribeiro NV, Lemos S, Escada P. Predatory publishing: an industry threatening science. Acta Med Port. 2018;31:1413.

2. Clark J. Letter to the editor - predatory journals: bad for all but especially authors from low and middle income countries. Acta Med Port. 2018;31:181-5.

3. Beall J. Beall's list of predatory journals and publishers. [accessed 2018 Apr 2]. Available from: https://beallslist.weebly.com/.

4. Anderson R. Cabell's new predatory journal blacklist: a review. [accessed 2018 Apr 2]. Available from: https://scholarlykitchen.sspnet. org/2017/07/25/cabells-new-predatory-journal-blacklist-review/.

5. Cabell Scholarly Analytics' Black List. [accessed 2018 Apr 2]. Available from: https://www2.cabells.com/about-blacklist.

6. Mazières $D$, Kohler E. Get me off your fucking mailing list. [accessed 2018 Apr 2]. Available from: http://www.scs.stanford.edu/ dm/home/ papers/remove.pdf.

7. Stribling J, Krohn M, Aguayo D. SClgen - An automatic CS paper generator. [accessed 2018 Apr 2]. Available from: https://pdos.csail.mit. edu/archive/scigen/.

\section{João GAMA MARQUES $\rrbracket^{1,2}$}

1. Hospital Júlio de Matos. Centro Hospitalar Psiquiátrico de Lisboa. Lisboa. Portugal.

2. Clínica Universitária de Psiquiatria e Psicologia Médica. Faculdade de Medicina. Universidade de Lisboa. Lisboa. Portugal.

Autor correspondente: João Gama Marques. joaogamamarques@gmail.com

Recebido: 02 de abril de 2018 - Aceite: 03 de abril de 2018 | Copyright $\odot$ Ordem dos Médicos 2018

https://doi.org/10.20344/amp.10599
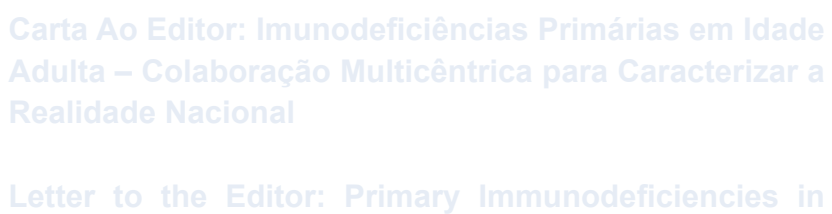

Adults - Multicentric Cooperation to Characterize the Portuguese Reality
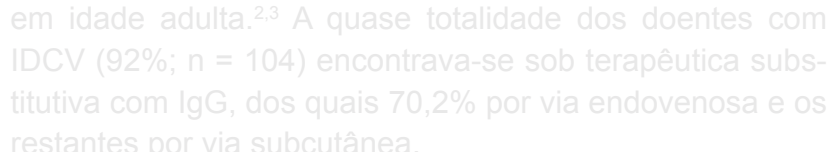